\title{
Henning Börm, Nino Luraghi (eds.), The Polis in the Hellenistic World, Franz Steiner Verlag, Stuttgart 2018, 262 pp., b/w ills., ISBN 978-3-515-12020-3
}

Studies of the history of ancient cities, an important part of historical research on ancient Greece and Rome, have developed their own research methods. These are determined by the varied types of historical evidence: literary, narrative, epigraphical, numismatic, iconographic and archaeological. Since these come from diverse historical periods and different areas of the ancient world, two concepts are usually applied in studies of ancient cities: the Greek polis and its Roman counterpart. These concepts serve to emphasise their varying legal status, organisation of socio-political life, urban structure etc. For some time, one further concept has been emerging and growing in popularity in this field: that of the Hellenistic polis.

Much attention has been devoted in recent years to the history of cities in the Hellenistic period, as demonstrated by numerous publications and academic conferences. The materials from two such conferences are published in the recent volume: The Polis in the Hellenistic World. The first took place in 2014 at the University of Konstanz, and the second in 2015 at Princeton University. The objective of the conferences was to showcase selected issues from the history of Hellenistic poleis. The book presents these problems in ten articles. Some of these concern issues and phenomena appearing in a large part of the Hellenistic world. Others concern questions of a more local scope, related to the history of a particular city or region or an especially interesting phenomenon.

Among the subjects that go beyond the narrow framework of local history is that of the economic life of Hellenistic poleis, the prevailing social conditions, and the political relations between them. The economic life of these cities is investigated by G. Oliver ("People and Cities: Economic Horizons Beyond the Hellenistic Polis," pp. 159-179). Discussion of this subject is particularly significant since the views on the issue formed by A. Bresson and M. I. Finley, in the light of the source data collected following the publication of their studies, provides a different perspective today on the economic foundations of the Hellenistic poleis. This is especially true because this new angle highlights elements that were previously not fully appreciated, or overlooked entirely. This applies in particular to the question of the impact of the political and social context in which the cities functioned in the Hellenistic period. The need to adjust to the new political realities was the greatest challenge they faced, especially smaller ones. The author analyses the problem in three dimensions: continuation and change, from the point of view of the poleis' trading and political activity, and the mobility of their inhabitants and their ability to form networks of mutual connections (pp. 161-176). Residents' economic activity within the situation that the political system of their home cities stipulated became an 
important development tool at the time. In the political sphere, a factor favouring the development of smaller urban centres and allowing them to play a greater role was their belonging to political leagues or federations, although this did not always guarantee them success on account of the rivalry between these political bodies, as well as the strong influence of the Hellenistic monarchies.

The papers by C. Ando ("The Political Economy of the Hellenistic Polis: Comparative and Modern Perspectives," pp. 9-26) and C. Müller ("Oligarchy and the Hellenistic City," pp. 27-52) have a great deal in common. Despite the somewhat misleading title of Ando's contribution, like Müller he is interested in the role of the upper social strata in the democratic system of the Hellenistic cities, emphasising the fact that the economic privilege of these classes guaranteed them complete power over the other groups of residents. Müller reaches similar conclusions. ${ }^{1}$ As a result of this situation, the concept of oligarchy disappeared from the political language of the era. According to Ando, the differing historical realities compared to the classical period require a change in the conception of democracy in the Hellenistic period, since its form at the time does not fit within Aristotle's categories. The results of the analyses and conclusions of the two scholars in question are complemented in H. Börm's article ("Stasis in Post-classical Greece: The Discourse of Civil Strife in the Hellenistic World," pp. 53-83), which explores social unease and its sources in Hellenistic cities. The author is interested in two questions: what were the causes of the contemporary civil strife identified by Greeks living in Hellenistic times, and how did the emergence of the Hellenistic monarchies affect the perception of this unrest (p. 58). Analyses of sources leads him to the conclusion that the answer to these questions is no different from what we know about the nature of such unrest from the earlier period: the main reason was rivalry between various groups of the cities' residents. They were usually confined to one city, making outside intervention unnecessary. According to the author, the considerably higher number of examples of civil strife that we know of in the Hellenistic period by no means points to a dramatic increase in their incidence as a result of socio-political realities. The main reason we are aware of these examples is the much larger number of sources available on their subject.

The political phenomena associated with the functioning of Hellenistic cities are presented by A. Magnetto ("Interstate Arbitration as a Feature of the Hellenistic Polis: Between Ideology, International Law and Civic Memory," pp. 85-107), P. Funke ("Poleis and Koina: Reshaping the World of the Greek States in Hellenistic Times," pp. 109-129) and F. Daubner ("Peer Polity Interaction in Hellenistic: theoroi Going to Epirus and Macedonia," pp. 131-157). A. Magnetto is interested in the high popularity of solving disputes between the Hellenistic cities through arbitration. Although this practice was known in the Greek world as soon as the sixth century BCE, during the Hellenistic period it was particularly common. The author examines the significance of arbitration as a method for regulating relations between Hellenistic poleis in the complex political context of the period, an inextricable part of which were the Hellenistic kings and Rome, as arbiters and guarantors of the sanctity of adjudications that had been made. The huge importance of arbitration institutions is revealed in two ways: first, the

1 "Nonetheless, all the cases we have looked at display a common point, not immune from paradoxes: the close intertwining of democracy and oligarchy. The two terms are not in opposition, nor do they form the two sides of the same coin" (p. 49). 
honours accorded to those citizens who served their home cities in this way, and second, the publication - in the form of inscriptions - of the documents setting out the decrees of the arbitration. P. Funke, meanwhile, points to the reasons for the popularity and the role of various forms of political unions in the Hellenistic world. What made this form of political organisation popular was the fact that small cities belonging to political leagues or federal states became able to protect their interests more effectively, and in external relations had greater prestige and status as their members. Furthermore, the representatives of urban elites, even in small cities, were given the opportunity for glittering careers by their participation in organisational structures. The picture the author paints of the role of political bodies in the Hellenistic period fully justifies his claim that "the federal states contributed to a revitalisation of its poleis in Hellenistic times, which then take on entirely different trajectories through the intervention of Rome" (pp. 125-126). F. Daubner, meanwhile, uses epigraphic evidence to prove the existence of strong links between the elites of the cities of northern Greece and the pan-Hellenic network of temples in Greece. In order to illustrate these connections, he uses inscriptions containing lists of theorodokoi, the local entertainers of sacred envoys of Greek temples, who visited the cities of Epirus and Macedonia between the fourth and the second century BCE. These documents come from Epidaurus, Argos, Nemea and Delphi. These links also confirm that for the social elites of the cities of northern Greece they were evidence of their affiliation to the Hellenistic world.

The remaining texts tackle issues of a somewhat different nature. A. Chaniotis ("The Polis after Sunset: What is Hellenistic in Hellenistic Night?," pp. 181-208) attempts to explain the role played by night time in social and religious life in the Hellenistic period. The fact that it sometimes entailed major activity of the inhabitants of cities is suggested by numerous sources. According to the author, this phenomenon cannot be explained solely by the significant amount of evidence, but must be attributed above all to the changes that took place in this era in almost all areas of life. This is particularly reflected in the military, social and religious spheres. In this period, night became a time when besieged cities were attacked, as well as that of religious practices associated with the increasingly popular mystery cults and widespread magical practices. Among the factors that contributed to the prolonging of human activity to the night time were wealthy residents paying for nocturnal street lighting, new types of illumination, and even the fact that public baths operated after dark. N. Luraghi ("Documentary Evidence and Political Ideology in Early Hellenistic Athens," pp. 209-227) endeavours to explain the functions of certain aspects of political ideology visible in the texts of the Athenian decrees from the Hellenistic period. He reaches the conclusion that "Athenian political ideology appears to have mandated interpreting as far as possible the consequences of the international context on the political life of the Athenians in terms of internal politics" (p. 220). ${ }^{2}$ The final article in this volume concerns philosophical issues. H.-U. Wiemer ("A Stoic Ethic for Roman Aristocrats? Panaitios' Doctrine of Behavior, Its Context and Its Addressees," pp. 229-258) analyses the first two books of Cicero's De officis,

2 Cf. p. 224: "It could be said that the documents I have discussed ... provide distorted reports of the events they pretend to refer to. This however would be a reductive and unhelpful conclusion, because at a closer scrutiny there is a clear and consistent logic to their distortion. This logic, in turn, is motivated by what I have called the political ideology of the Athenian democracy." 
attempting to determine what Panaitios' doctrine of behavior looked like, and what its influence on the Romans was. Wiemer concludes that Panaitios addressed his doctrine to the higher social groups of the cities of the Hellenistic world, whose position and social role largely recalled the one occupied by Roman aristocrats. As a result, Cicero was able to adapt the Greek philosopher's views to Roman socio-political realities and make them into the philosophical foundation of the lifestyle of Roman senators. The considerable dependence of Cicero's views on Panaitios' conceptions makes it possible to reconstruct the Hellenistic philosopher's views relatively accurately.

Despite its relatively modest size, The Polis in the Hellenistic World can be recommended to a wide range of scholars interested not only in the Hellenistic period, but especially those with a particular focus on the history of the polis in the broadest terms. An undoubted value of the book is the broad range of methodological approaches employed by the authors of the various texts, along with the extensive range of the problems they analyse. This means that their conclusions significantly expand readers' understanding life and place of the polis in the Hellenistic era. They also provide further convincing arguments for the legitimacy of using the notion "Hellenistic polis" in academic literature to refer to one containing markedly different contents from the classical definition of the Greek polis.

Edward Dąbrowa (Jagiellonian University in Kraków) 